\title{
Ad Hoc Board's Ethics and Conduct Code Violation in Bolaang Mongondow General Election Commissions (KPU)
}

\author{
Ni Made Desika Ermawati Putri \\ Faculty of Law, Universitas Udayana, Denpasar, Bali, Indonesia \\ Email: desikaputri86@gmail.com \\ ORCID Link: https://orcid.org/0000-0003-0982-6944
}

\section{Citation:}

Putri, N. M. D. E. (2021). Ad Hoc Board's Ethics and Conduct Code Violation in Bolaang Mongondow General Election Commissions (KPU), Lex Scientia Law Review, 5(1), 25-44, doi: https://doi.org/10.15294/

lesrev.v5i1.45725

History of Article

Received: March 13, 2021

Revised: May 17, 2021

Accepted: May 27, 2021

(C) The Author(s)

\section{(c) (1) 8 ()}

This work is licensed under a Creative Commons Attribution-NonCommercialShareAlike 4.0 International License. All writings published in this journal are personal views of the authors and do not represent the views of this journal and the author's affiliated institutions.

Lex Scientia Law Review published by Faculty of Law, Universitas Negeri Semarang, Indonesia in collaboration of UKM Lex Scientia. Published biannually every May and November.

\begin{abstract}
The purpose of this study was to determine the implementation of repressive and preventive actions of the Ad Hoc board's Ethics and Conduct Code in Bolaang Mongondow KPU. The research method used was empirical legal research methods, the data were from primary and secondary data with data collection techniques used were documents study and interview. The data were analyzed using qualitative data analysis, where all collected data were analyzed, connected into one another, and presented descriptively and systematically. Based on the study results, it is known that the repressive and preventive mechanism of the Ethics and Conduct Code of Ad Hoc Board of Bolaang Mogondow KPU in organizing Election for the Governor and Deputy Governor of North Sulawesi in 2020 had been carried out in accordance with statutory regulations. There were 5 (five) cases of Ethics and Conduct Code violations carried out by the Ad Hoc Board within the Bolaang Mongondow KPU.
\end{abstract}

\section{KEYWORDS}

General Election Commission (KPU); Repressive action; Violation 


\section{INTRODUCTION}

General Election Commission (Komisi Pemilihan Umum - KPU) is an institution which, according to Indonesian law, has the task of organizing general elections that are national, permanent and idependent. ${ }^{1}$ According to Prof. Jimly As-Shidqie, KPU is a state election organizer institution whose duties and authorities have been determined by law and cannot be aligned with other state institutions. KPU is an election organizer institution to elect the president and the vice president, members of the representatives, and elect the governor, regent/mayor and their deputies. ${ }^{2}$ In orgizing elections, KPU has duties and authorities to conceptualize norms, make designs, programs, and coordinate all election stages with the Provincial and Regency/City levels KPU, which has the task of carrying out all the election stges at the respective regional levels. ${ }^{3}$ The Law on General Elections defines KPU as an election management institution that is national, permanent and independent in carrying out general elections. KPU consists of Provincial level KPU and Regency/City level KPU as stipulated in Article 1 point 9 of the Law on General Elections.

Moh. Kusnardi and Harmaily Ibrahim defined General Election, hereinafter referred to as Election, as a way to elect people's representatives and must be held at certain times. Bagir Marian stated that "The five-year cycle elections are a time or momentum to show real and direct people government. At that time, all candidates wishing to sit as state and government administrator depend entirely on the people will." ${ }^{4}$ Elections exist in countries with democratic forms of government. The democracy itself is the power that comes from the people which has a logical consequence that the pople have the power to determine and make rules so that they can protect their rights. ${ }^{5}$ Elections held by the KPU are the means for achieving a democratic government. They manifest the people's sovereignty to roduce a democratic state government based in Pancasila and the 1945 Constitution of the Republic of Indonesia. So far, since Indonesia's independence until today, elections are still believed to be the fairest means for the people to elect their representatives in the government (executives and legislatives) and become

\footnotetext{
${ }^{1}$ B Basriadi. (2009). Tugas dan Kewenangan KPU dalam memverifikasi partai politik peserta pemilu di Indonesia menurut UU no. 2 tahun 2008 dan UU no. 10 tahun 2008 dalam perspektif fiqh siyasah (Doctoral dissertation, IAIN Sunan Ampel Surabaya). p. 31.

2 Jimly Asshiddiqie. (2006). Pengantar Ilmu Hukum Tata Negara. Jakarta: Sekretariat Jenderal dan Kepaniteraan Mahkamah Konstitusi. p.3

${ }^{3}$ S Warjiyati. "Penataan Struktur dan Kewenangan Komisi Pemilihan Umum, Badan Pengawas Pemilu dan Dewan Kehormatan Penyelenggara Pemilu dalam Upaya Mewujudkan Pemilihan Umum yang Demokratis di Indonesia". ARISTO, 8(1), 2020. p. 29.

${ }^{4}$ Ibid.

${ }^{5}$ Cora Elly Noviati, "Demokrasi Dan Sistem Pemerintahan", Jurnal Konstitusi, 10.2, 2013. p. 334.
} 
competition means for candidates from each political party or political party coalition to be able occupying political positions in Indonesia. ${ }^{6}$

One of the election implementation, which then became the focus of this research, is the election of the Regent and Deputy Regent of North Sulwesi in 2020 which was a means of people's sovereignty to elect their executives and supposed to be carried out directly, publicly, freely, secretly, honestly and fairly. In carrying out its duties, Bolaang Mongondow KPU is guided by the principle of independence, honesty, fairness, legal certainty, orderly, public interest centerly, openness, proportionality, professionality, accountability, efficiency and effectiveness. If those principles are connected with the previous explanation that the election held by Bolaang Mongondow KPU was a means to create a democratic government in Indonesia especially in that regency, they are in line with Jimly Asshiddiqie's statement that political parties and the election including its organizer are an integral instrument to create a climate of democracy in Indonesia. ${ }^{7}$

The working area of Bolaang Mongondow KPU consists of 15 (fifteen) districts namely: Poigar District, East Bolaang District, Bolaang District, Lolak District, Sangtombolang District, West Passi District, East Passi District, Bilalang District, Lolayan District, Dumoga District, Center Dumoga District, East Dumoga District, North Dumoga District, South East Dumoga District and West Dumoga District, and also consists of 200 (two hundred) villages and 2 (two) sub-districts. In carrying out its duties at sub-district and village level, Bolaang Mongondow KPU is assisted by the Ad Hoc Board, namely the District Election Committee (Panitia Pemilihan Kecamatan - PPK) at the district level and the Voting Committee (Panitia Pemungutan Suara - PPS) at the village and sub-district level. The $A d$ Hoc Board is selected and appointed at the election periode and ended when the election is over, with honorarium which its amount is determined by Indonesian laws and regulations. ${ }^{8}$ The number of PPK in Bolaang Mongondow Regency is 75 (seventy five) people, while the number of PPS is 606 (six hundred six) people. In voting and counting votes implementation, Bolaang Mongondow KPU is assisted by the Voting Organizer Group (Kelompok Penyelenggara Pemungutan Suara KPPS) in 514 (five hundred and fourteen) TPS totaling 3.598 (three thousand five hundred ninety eight) people. In carrying out its duties, the Ad Hoc Board

${ }^{6}$ Didik Sukriono, "Menggagas Sistem Pemilihan Umum Di Indonesia", Jurnal Konstitusi Kanjuruhan, 2.1, 2009. p. 10-11.

7 Jimly Asshiddiqie, "Partai Politik Dan Pemilihan Umum Sebagai Instrumen Demokrasi", Jurnal Konstitusi, 4.2, 2006. p. 6

8 Syamsul Khan and Yusa Djuyandi "Implementasi Regulasi Pemilihan Umum Tahun 2019 Yang Tidak Matang (Studi Kasus KPU Kab. Banggai)", Wacana Publik, 14.2, 2020. p. 24. 
must be guided by the positive laws and regulations and if the Ad Hoc Board does not behave in accordance with the provisions they will be subject to sanction.

Major violations that are often commited and even without being aware of by the Ad Hoc Board are violation of the Ethics and Conduct Code. Based on Article 136 Law Number 1 of 2015 concerning Stipulation of Government Regulations in Lieu of Law Number 1 of 2014 concerning the Governors, Regents, and Major Election into law as amended several times, most recently by Law Number 6 of 2020 concerning Stipulation Government Regulation in Lieu of Law Number 2 of 2020 concerning the Third Amendment to Law Number 1 of 2015 concerning Stipulation of Government Regulation in Lieu of Law Number 1 of 2014 concerning the Governors, Regents, and Major into Law, stated that violation of Ethics Code of the election organizer is a violation of the violation of election organizer's ethicss based on oath and/or promise before carrying out their duties as and election organizer.

Furthermore, based on Article 10A Election Organizer Honorary Council (Dewan Kehormatan Penyelenggara Pemilihan Umum - DKPP) Regulation Number 3 of 2017 as amended by the DKPP Regulation Number 2 of 2019, it stated that in the case of the Defendant andor Reported Party, namely Election Organizer who serves as a member of PPK, PPS or KPPS, which complains and/or reports are submitted directly to the KPU or regency/city level KPU or regency/city level Bawaslu by referring to the KPU or Bawaslu Regulations. Also Article 15 stated that complains and/or reports of Conduct Code violations are subject to administrative verification by the KPU or regency/city level KPU. KPU had stipulated provisions regarding Ethics Code violation, namely in KPU Regulation Number 8 of 2019 concerning Work Procedures for KPU, Provincial Level KPU, and Regency/City Level KPU as amended by KPU Regulation Number 3 of 2020 concerning Amendments to the KPU Regulation Number 8 of 2019 concerning Work Procedures for KPU, Provincial Level KPU, and Regency/City Level KPU and the KPU Decree Number 337/HK.06.2-Kpt/01/KPU/VII/2020 concerning Technical Guidelines for Repressive Action against Violation of Ethics and Concuct Code, Oath/Promise, and/or Integrity Pact of the PPK, PPS, and KPPS.

This research problem was formulated based on the explanation above, that was how is the implementation of repressive action against the Ethics and Conduct Code violation of the Ad Hoc Board at the Bolaang Mongondow KPU? The purpose of this study was to determine the implementation of repressive action against the Ethics and Conduct Code violation of the Ad Hoc Board at the Bolaang Mongondow KPU. As for previous study that was similar to this research, by Kiani Irena Maki, Donald A. Rumokoy and Carlo 
A. Gerungan, in their research entitled "Kewenangan Dewan Kehormatan Penyelenggara Pemilu Republik Indonesia Dalam Memutus Pelanggaran Kode Etik". That research aimed to find out what forms of Ethics Code violation of the election organizer which were the object of the DKPP authority to decide the cases, and what were the legal consequences of the DKPP decisions on election organizers who violated the Ethics Code. The results of the study concluded that th violaton of the Ethics Code was the election organizer failure to comply with the principles of their Ethics Code, the denial of their professions oaths/promises were also included in the violation of the election organizer Ethics Code. The form of legal consequences of the DKPP decision against election organizer who violate Ethics Code is only a recommendation becase its implementation cannot be enforced by DKPP. This situation creates legal uncertainty in the implementation of the DKPP decisions and shows us that the authority of DKPP RI in deciding Ethics Code violatin can still be said to bee weak in its implementation. ${ }^{9}$

Other research similar to this had been conducted by Aidinil Zetra, Emeraldy Chatra and Yulia Sari etitled "Pelanggaran Kode Etik Berat Oleh Anggota KPU Kabupaten/ Kota di Provinsi Sumatera Barat Pada Pemilu Tahun 2014 Dan Pilkada Tahun 2015". Those study aimed to describe the process of the serious violation of the Ethics Code. Based on those research, it was known that the Ethics Code violation by five members of the regency/city level KPU in West Sumatra was committed because there were special incidents in the implementation of the election stages, which were not in accordance with election or regional election provisions. Those study also illustrated that te Ethics Code violation committed by regency/city level KPU members in West Sumatra was due to the lack of eletoral matters knowledge. ${ }^{10}$

Another one similar to this study was also conducted by Angga Akbar entitled "Pemberhentian Anggota Komisi Pemilihan Umum Berdasarkan Pelanggaran Kode Etik". The research discussed the problem of Ethics Code violation that was solved by DKPP. Based on the study results, it was concluded that the neutrality factor was the main reason for the dismissal of election organizer members beside the imbalance factor and bribery cases, as

\footnotetext{
${ }_{9}^{9}$ Kiani Irena Maki, Donald A. Rumokoy, and Carlo A. Gerungan, "Kewenangan Dewan Kehormatan Penyelenggara Pemilu Republik Indonesia Dalam Memutus Pelanggaran Kode Etik", Lex Administratum, 8.4, 2020. p. 12.

${ }^{10}$ Emeraldy Chatra and Yulia Sari Aidinil Zetra, 'Pelanggaran Kode Etik Berat Oleh Anggota KPU Kabupaten/ Kota Di Provinsi Sumatera Barat Pada Pemilu Tahun 2014 Dan Pilkada Tahun 2015', Jurnal Ilmu Sosial, 16.1, 2017. p. 26.
} 
well as the nature of DKPP decision which is final and an appeal is not fully interpreted as in other general judicial institutions, because in its implementation the DKPP decision must go through the decision of the relevant election organizer institution, so that a lawsuit can be filed at the State Administrative Court (PTUN). ${ }^{11}$ As can be seen and compared this study with another 3 (three) similar previous studies, it can be firmy said that this study has different focus with previous study, so it is important to do this research.

\section{METHOD}

The research method used in this study was an empirical legal research method. In this research, law was conceptualized as an empirical symptom that can be observed in real life, or in othe words, a study conducted on the actual situation or real conditions that occur in society with the intention of knowing and finding data needed. After the required data was collected, it lead to the problem identificatioon which turned in to problem solving. ${ }^{12}$ The data used were primary and secondary data. Primary data was collected by research conduted in the field, meanwhile secondary data consisting of statutory regulations, ministerial regulation, village regulations, books, journals and other literature related to the discussion of repressive action against Ethics and Conduct Code violation committed by Ad Hoc Board, dictionaries and internet sites. This research is descriptive in nature, which described the repressive action against Ethics and Conduct Code violation committed by Ad Hoc Board in Bolaang Mongondow KPU. Data collection techniques used in this study were document study and interview. Document study were carried out at an early stage to see legal materials that were relevant to the research discussion. The interview aimed to obtain answers that were relevant to the research problem originally from the informant. The informant for this study was the Head of the Law and Supervision Division of Bolaang Mongondow. The data analysus used in this researcg was qualitative data analysis. All collected data were analyzed, linked to one another and presented descriptively and systematically.

\section{RESULT AND DISCUSSION}

\section{A. Repressive Action against Ethics and Conduct Code Violations in Bolaang Mongondow KPU}

According to the Big Indonesian Dictionary (KBBI), codes of ethics are norms and principles accepted by certain groups as a basis for acceptable

\footnotetext{
${ }^{11}$ Angga Akbar, "Pemberhentian Anggota Komisi Pemilihan Umum Berdasarkan Pelanggaran Kode Etik" (Universitas Sriwijaya, 2019). p. 5.

${ }_{12}$ Waluyo, B. (2002). Penelitian Hukum Dalam Praktek. Jakarta: Rineka Cipta, p.16.
} 
behavior. ${ }^{13}$ An Ethics Code can also be intepreted as a pattern of rules, procedures, commas, ethical guidelines in carrying out an activity or job. An Ethics Code is a pattern of rules or procedures to guide behavior and culture. ${ }^{14}$ Code of Condut is a guide to action or action based on values, ethics and work culture that employees must comply with in carrying out their duties, organizational functions and peronal life.

The legal bases in repressive action against Ethics and Conduct Code violations in Bolaang Mongondow KPU are as follows;

1. Law Number 1 of 2015 concerning Stipulation of Government Regulations in Lieu of Law Number 1 of 2014 concerning the Governors, Regents, and Major Election into law (Republic of Indonesia's State Gazette of 2015 Number 23, Republic Indonesia's Supplement to State Gazette Number 5656) as amended several times, most recently by Law Number 6 of 2020 concerning Stipulation Government Regulation in Lieu of Law Number 2 of 2020 concerning the Third Amendment to Law Number 1 of 2015 concerning Stipulation of Government Regulation in Lieu of Law Number 1 of 2014 concerning the Governors, Regents, and Major into law (Republic of Indonesia's State Gazette of 2020 Number 193, Republic Indonesia's Supplement to State Gazette Number 6547).

2. DKPP Regulation Number 2 of 2017 concerning Ethics and Conduct Code of KPU (Republic Indonesia's State Gazette of 2017 Number 1338).

3. DKPP Regulation Number 3 of 2017 concerning Guidelines for Conducting the Ehic and Conduct Code for KPU (Republic Inonesia's State Gazette of 2017 Number 1404) as amended by DKPP Regulation Number 2 of 2019 (Republic Indonesia's State Gazette of 2019 Number 291).

4. KPU Regulation Number 3 of 2015 concerning the Work Procedures of the KPU, the Provincial Level KPU/Independent Election Commission of Aceh and KPU/Independent Election Commission of Regency/City, Establishment of Work Procedures for PPK, PPS and KPPS in Organizing Election for Governors, Regents and Deputy Regents and/or Mayors and Deputy Mayors as amended most recently by the KPU Regulation Number 13 of 2017.

\footnotetext{
${ }^{13}$ Departemen Pendidikan dan Kebudayaan Republik Indonesia. (1988). Kamus Besar Bahasa Indonesia. Jakarta: Balai Pustaka, p. 321.

${ }^{14}$ P.F. Ziha. (2018). Implementasi Peraturan Menteri Pekerjaan Umum Dan Perumahan Rakyat Nomor 7 Tahun 2017 Tentang Kode Etik Dan Kode Perilaku Pegawai Dalam Meningkatkan Kinerja Pegawai Di Balai Besar Pelaksanaan Jalan Nasional Ii Medan (Doctoral dissertation). p. 21.
} 
5. KPU Regulation Number 8 of 2019 concerning concerning Work Procedures for KPU, Provincial Level KPU, and Regency/City Level KPU ((Republic Indonesia's State Gazette of 2019 Number 320) as amended by KPU Regulation Number 3 of 2020 concerning Amendments to the KPU Regulation Number 8 of 2019 concerning Work Procedures for KPU, Provincial Level KPU, and Regency/City Level KPU (Republic Indonesia's State Gazette of 2020 Number 201).

6. KPU Regulation Number 15 of 2019 concerning te Stages, Programs and Schedules for Organizing the Election for Governor and Deputy Governors, Regents and Deputy Regents and/or Mayors and Deputy Mayors in 2020 (Republic Indonesia's State Gazette of 2019 Number 905) as amended several times, most recently by KPU Regulation Number 5 of 200 concerning the Third Amendment to the KPU Regulation Number 15 of 2019 (Republic Indonesia's State Gazette of 2020 Number 615).

7. KPU Decree Number 337/HK.06.2-Kpt/01/KPU/VII/2020 concerning Technical Guidelines for Repressive Action against Violation of the Ethics and Conduct Code, Oaths/Promises and/or Integrity Pact of Members of the PPK, PPS and KPPS.

8. North Sulawesi KPU Decree Number 69/PP.01.2-Kpt/71/Prov/VI/2020 concerning the Second Amandment to the North Sulawesi KPU Decree Number 138/PP.01.2-Kpt/71/Prov/X/2019 concerning Technical Guidelines for Stages, Programs and Schedules for Organizing the 2020 North Sulawesi Governor and Deputy Governor Election.

Based on these laws and regulations, it is known that the process for doing repressive action against the Ethics and Conduct Code violation by Ad Hoc Board in Kabupaten Bolaang Mongondow KPU was as follows; ${ }^{15}$

1. The establishment of a Team for Receiving Reports and/or Complaints of Ethics and Conduct Code Violation conducted by PPK, PPS and KPPS in the 2020 election for the Governor and Deputy Governor of North Sulawesi in the Bolaang Mongondow KPU. It was determined by the Bolaang Mongondow KPU Decree Number: 199/HK.06.4-Kpt/7101/KPU$\mathrm{Kab} / \mathrm{VII} / 2020$ concerning the Formation of a Team for Receiving Reports and/or Complaints of Violation of the Ethics Code, Code of Conduct, Oaths/Promises and/or Integrity Pacts committted by PPK, PPS and KPPS in the 2020 Election for the Governor and Deputy Governor of North Sulawesi in the Bolaang Mongondow KPU;

2. The Team received the reports contained in the PE-1 Model and PE-2 Model Forms in the KPU RI Decree Number: 337/HK.06.2-

\footnotetext{
${ }^{15}$ Interview, Ketua Divisi Hukum dan Pengawasan KPU Kabupaten Bolaang Mongondow, 23 Februari 2021.
} 
Kpt/01/KPU/VII/2020 concerning Technical Guidelines for Doing Repressive Action against Violation of the Ethics Code, Code of Conduct, Oaths/Promises and/or Integrity Pacts by the Members of PPK, PPS and KPPS;

3. The Team examined the reports/complains by clarified and wrote those down in the PE-3 Model Form in the KPU RI Decree Number: 337/HK.06.2-Kpt/01/KPU/VII/2020 concerning Technical Guidelines for Doing Repressive Action against Violation of the Ethics Code, Code of Conduct, Oaths/Promises and/or Integrity Pacts by the Members of PPK, PPS and KPPS. In this case, Bolaang Mongondow KPU invited all of the parties to be asked for clarify;

4. Furthermore, the results of clarification was brought to a plenary meeting attended by all members of Bolaang Mongondow KPU to determine whether the violation would be continued until the examination stage in trial;

5. Furthermore, if the violation was continued to the examination stage in trial, the related parties will be summoned, in this case the Bolaang Mongondow KPU would make an invitation to hold an examination trial;

6. After the examintation trial was held, the Examination Team reviewed the results in accordance with the trial facts and based on statutory regulation, as a Plenary Meeting had been held in order to discuss the results of the Examination Team's study as stated in the PE-4 Model Form, namely the Minutes of Results of Repressive Action against Alleged Ethics and Conduct Code Violations;

7. Furthermore, reports on Ethics and Conduct Code violations are reported to the Honorary Council of Election Organizer (DKKP) through the North Sulawesi KPU as outlined in PE-5 Model Form.

The Ethics and Conduct Code violations that occured at Bolaang Mongondow KPU were such as; ${ }^{16}$ Ethics and Conduct Code violation committed by the PPS Pasir Putih Chairperson, initial KM, who did not carry out his duties as the PPS Pasir Putih Cairperson, Sangtombolang District, Bolaang Mongondow. The follow-up carried out by the Bolaang Mongondow KPU related to this case were as follows:

a. Team for Receiving Reports and/or Complaints of Ethics and Conduct Code Violation conducted by PPK, PPS and KPPS in the 2020 election for the Governor and Deputy Governor of North

\footnotetext{
${ }^{16}$ Interview, Ketua Divisi Hukum dan Pengawasan KPU Kabupaten Bolaang Mongondow, 23 Februari 2021.
} 
Sulawesi in the Bolaang Mongondow KPU, received the report contained in the PE-2 Model Form on August 3, 2020. It was reported by the Sangtombolang PPK;

b. The Team collected evidence and information by Bolaang Mongondow KPU directly asked for information from PPS members and PPS Secretariat from Pasir Putih Village as witnesses as well as related parties in cases of the violation reported committed by Karim Mokodompit as Chairperson of Pasir Putih PPS

c. Furthermore, the Bolaang Mongondow KPU asked for evidence of whether the person concerned did not perform his duties as PPS Chairperson, it was evidenced by the attendance list of activitie and plenary meetings, where the person concerned did not attend several activities and plenary meetings;

d. With the witness's testimony and evidence, the Bolaang Mongondow KPU made a clarification invitation and made a clarification to Karim Mokodompit. In that clarification he stated that he wanted to resign from the Ad Hoc Board and admitted that he had not participated in several activities and plenary meetings that had been held.

Ethics and Conduct Code violation carried out by the PPS Secretariat of West Sinsingon Village initial KM who was a member of political party in West Singsingon, East Passi District, Bolaang Mongondow Regency. The follow-up carried out by the Bolaang Mongondow KPU related to this case is as follows:

a. The Team received the report contained in the PE-1 Model Form on August 27, 2020. It was reported by the Regional Coordinator of East Passi District, namely Mr. Ingga Adampe, A.Md. based on the results of internal supervision;

b. The Team collected evidence and information on reports received by Bolaang Mongondow KPU directly to West Sinsingon and asked for information from PPS members and PPS Secretariat as witnesses as well as related parties in Ethics and Conduct Code violation committed by Kendi Momongan as a member of the West Sinsingon PPS;

c. Furthermore, the Bolaang Mongondow KPU made a clarification invitation to Kendi Momongan, in the clarification he stated that he was a member of a political party and was willing to resign from the Ad Hoc Board. That clarification had been stated in the Minutes of the Bolaang Mongondow KPU Number: 144 /HK.06.4-BA/7101/KPUKab/VIII/2020 concerning Clarification of Public Reports Towards the PPS Secretariat of West Sinsingon Village, East Passi District in the 
Election of Governor and Deputy Governor of North Sulawesu in 2020.

Ethics and Conduct Code violation committed by Tanjung Mariri PPS Member, Poigar District initial AK, who gave a response sign of liking on social media, Facebook, on a party flag picture. The follow-up carried out by the Bolaang Mongondow KPU related to this case were as follows;

a. Bolaang Mongondow KPU received a letter from Bolaang Mongondow Bawaslu regarding Tanjung Mariri PPS Member, Poigar District, which was a finding in Ethics and Conduct Code violation;

b. On Wednesday, August 26, 2020 at the Secretariat Office of the Bolaang Mongondow KPU, summons and clarifications were made to the complainants, reported, and related parties to be asked for information regarding the alleged Ethics and Conduct Code violation committed by Tanjung Mariri PPS Member, Poigar District, Bolaang Mongondow Regency on behalf of Anthon Kilapong as stated in the Minutes of Bolaang Mongondow KPU Number: 145/HK.06.4BA/7101/KPU-Kab/VIII/2020 concerning the Results of Clarification and Verification of Alleged Violation of the Ethics and Conduct Code of Ad Hoc Board;

c. On Friday, August 28, 2020 a call to attend the Examination Session of reporting and reported party, witnesses, and other related party had been made according to the Minutes of Bolaang Mongondow KPU Number: 145/HK.06.4-BA/7101/KPU-Kab/VIII/2020 concerning the Results of Clarification and Verification of Alleged Ad Hoc Board Ethics and Conduct Code Violations. They were invited to be asked for information and evidence on the report submitted by the reporting party as set forth in the PE-3 Model Form Examination of Ethics and Conduct Code Violations Report Number: 02/HK.06.4/7101/VIII/2020;

d. On Monday, August 31, 2020 from the results of the Examination Team's study, in accordance with the facts of the trial and based on statutatory regulations, a Plenary Meeting was held in order to discuss the results of their examination study along with recommendations for sanction. It was given as stated in the PE-4 Model Form, namely Minutes of Results of Repressive Action of Alleged Ethics and Conduct Code Violation Number: 151/HK.06.4BA/7101/KPU-Kab/VIII/2020. Then the report was submitted to DKPP through the North Sulawesi KPU as outlined in the PE-5 Model Form. 
Ethics and Conduct Code violation committed by KPPS Imandi Village members, East Dumooga District initial MS, AO and JK. They were wearing campaign attributes of a candidate pairs for North Sulawesi governor and deputy governor in 2020. The follow-up carried out by Bolaang Mongondow KPU related to this case were as follows:

a. The Team received the report contained in the PE-1 Model Form on November 25, 2020. The reporting party was East Dumoga District coordinator, Mr. Afif Zuhri, SE based on the results of internal supervision;

b. On Friday, November 27, 2020 the Team, at Bolaang Mongondow KPU Secretariat Office, summoned and clarified the reporting, reported, and other related parties to be asked for information regarding the alleged Ethics and Conduct Code violation committed by Imandi Village KPPS on TPS 2 by Anita Ompi and TPS 4 by Jeini Kemur and Martha Siwi. But, those concerned did not fulfill the call and did not clarify the report. Who came to the clarification was only Yuliadi Karuh as East Dumoga Paswacam. The clarification results had been stated in the Minutes Number: 240/HK.06.4-BA/7101/KPU-Kab/XI/2020 concerning Clarification of Related Parties on Alleged Ethics and Conduct Code, Oath/Promise and/or Integrity Pact in Continued Governor and Deputy Governor Election of North Sulawesi 2020;

c. Furthermore, on Saturday, November 28, 2020 at the Bolaang Mongondow KPU Secretariat Office, a recall and clarification were made to the reporting and reported parties to be asked for information on the alleged Ethics and Conduct Code violation. But the reported parties did not fulfill the call back and did not attend the summons for clarification. The related party who came to fulfill the invitation was only East Dumoga PPK. The results of the clarification had been stated in the Minutes Number: 241/HK.06.4-BA/7101/KPU-Kab/XI/2020 concerning Clarification of Related Parties on Alleged Ethics and Conduct Code Violation in the Election of Governor and Deputy Governor of North Sulawesi in 2020;

d. On Monday, November 30, 2020 accoring to the Minutes of Bolaang Mongondow KPU Number: 243/HK.06.4-BA/7101/KPU-Kab/XI/2020 concerning the Results of Clarification and Verification of Alleged $A d$ Hoc Body Ethics and Conduct Code Violations, a call had been made to 
attend the Examination Session for the reporting and reported parties, witnesses and related parties. They were invited to be asked for information and evidence on the report submitted by the reporting party as set forth in the PE-3 Model Form Examination of Ethics and Conduct Code Violations Report Number: 03/HK.06.4/7101/XII/2020;

e. On Tuesday, December 1, 2020 it was followed by an examination hearing of alleged Ethics and Conduct Code violations which was held at the Bolaang Mongondow KPU office at 1:00 p.m. with invitation number: 493/HK.06.4-Und/7101/KPU-Kab/XI/2020 on November 30, 2020;

f. Based on the examination results and accordance with the trial facts and based on statutary regulation, a Plenary Meeting was held in order to discuss the results of the Team's study as stated in the PE-4 Model Form, namely Minuters of the Results of Repressive Action of Alleged Ethics and Conduct Code Violation Number: 247/HK.06.4BA/7101/KPU-Kab/XII/2020.

Ethics and Conduct Code violation committed by Langagon Village PPS member initial HVG who made a Facebook post supporting one of the candidate pairs for Governor and Deputy Governor of North Sulawesi in 2020. The follow-up was carried out by the Bolaang Mongondow KPU related to this case were as follows;

a. On Monday, Desember 72020 in Bolaang Mongondow KPU Secretariat Office, the Team summoned and clarified the reporting, reported, and other related parties to be asked for information regarding the alleged Ethics and Conduct Code violation committed by Langagon Village PPS member on behalf of Hirawanto Van Gobel. The clarification result had been stated in the Minutes Number: 250/HK.06.4-BA/7101/KPU-Kab/XII/2020 concerning Clarification Result of Alleged Violation of the Ethics Code, Code of Conduct, Oaths/Promises and/or Integrity Pacts in North Sulawesi Governor and Deputy Governor Continued Election 2020;

b. On Monday, December 7, 2020 according to the Minutes of Bolaang Mongondow KPU Number: 298/HK.06.4-BA/7101/KPU-Kab/XII/2020 concerning the Results of Clarification of the PE-5 Model Form and Verification of Alleged Ethics and Conduct Code Violations at the 
Examination Session of the Reporting and Reported Parties, Witnesses and other Related Parties based on Report stated in the PE-3 Model Form, Examination Results of Violation of Ethics and Conduct Code, Oath/Promise, and Integrity Pact Report Number: 05/HK.06.4/7101/XII/2020;

c. On Thursday, December 10, 2020 from the results above, in accordance with the trial facts, and based on statutatory regulations, a Plenary Meeting was held in order to discuss the resuts of the Team's study as stated in the PE-4 Model Form, Minutes of Repressive Action Results of Alleged Ethics and Conduct Code Violations Number: 301/HK.06.4-BA/7101/KPU-Kab/XII/2020.

\section{B. Preventive Action against Ethics and Conduct Violation of Bolaang Mongondow KPU Ad Hoc Board}

According to KBBI (2007), prevention is a process, means, action to hold back so that something does not happen thus prevention is an action. Prevention is identical to behaviour. Article 1 point 4 of DKPP Regulation Number 2 of 2017 concerning Ethics and Conduct Code for KPU stated that the Ethics Code for Election Organizer, hereinafter referred to as the Ethics Code, is a unity of moral, ethical and philosophical principles that serve as a code of conduct for election organizers in the form of obligations or prohibitions, action and/or utterance that are appropriate or inappropriate to be carried out by an election organizer.

The word ethics in Greek is "ethos" which means habits, customs, character, feelings, attitudes, and ways of thinking. The term ethics is also called mores, mos which also means good customs so that from this term the moral or morality was born. ${ }^{17}$ The ethics term in the legal environment, especially business law, aims to protect the general public. ${ }^{18}$ Ethics is understood as a critical reflection on how humans should live and act in a concrete situation system, on certain special situation. Ethics is a moral philosophy, or science that critically discusses and eximanes the moral issue of what is right and wrong, of how to act in concrete situation. ${ }^{19}$ Ethics is an important element that must be adhered to by every election organizer consisting of the KPU, Bawaslu and their ranks from top to bottom. This is

\footnotetext{
${ }^{17}$ A. Fadlian, “Pengaruh Putusan Dewan Kehormatan Penyelenggara Pemilihan Umum terhadap Hasil Pemilihan Gubernur Lampung 2014". FIAT JUSTISIA: Jurnal Ilmu Hukum, 10(4), 2016. p. 784. ${ }^{18}$ Irham Fahmi, Etika Bisnis (Bandung: Alfabeta, 2013). p. 23.

${ }^{19}$ Raden Besse Kartoningrat, "Fungsi Etika Profesi Bagi Kurator Dalam Menjalankan Tugas", Jurnal Perspektif, 2.21, 2016. p. 118.
} 
one of the fundamental aspects in realizing democratic elections. The realization of democratic election can be achieved if the election organizers prioritize ethical values. Otherwise, if the election organizers violate their ethical values, it will hinder the realization of a democratic election in Indonesia. ${ }^{20}$

Broadly speaking, violations of election organizers Ethics Code can also be grouped into several types, including: ${ }^{21}$

1. Formal and Material Violations. Formal violation of Ethics Code is an election organizer action that can be categorized as a violation when that action meets the elements of the formulation of a prohibited act or an act that is not permitted to be committed according to the Ethics Code. Meanwhile, material violation refers to the impact or consequence of the Ethics Code violation.

2. Commission (actively commiting) and Omission (violating by not doing what should be done) Violations. Commission type of Ethics Code violation refers to actions that are actively committed by election organizers which are clearly prohibited by law and Ethics Code for election organizer. Meanwhile, the omission type of Ethics Code violation refers to the attitudes and actions of omission by the election organizers regarding a situation and actions that are known to be Election Law or Ethics Code violations.

3. Deliberate violation (dolus) and violation due to negligence (culpa). In this case, dolus in a deliberate act of violation committed by the election organizer. Meanwhile, culpa is type of violation that are not based on the intention to commit an act due to carelessness or inaccuracy resulting in losses to election participants.

The efforts to prevent Ethics and Conduct Code violation of Bolaang Mongondow KPU Ad Hoc Board are as follows:

1. Giving Firm and Fair Sanctions

In the application of imposing sanction on $A d H o c$ Board that violate the Ethics and Conduct Code, it must be done firmly, fairly and impartially. All Ad Hoc Board members are treated the same, for example those who violate the Ethics and Conduct Code are Poigar PPS and Bolaang PPS, then the sanctions given are in accordance with applicable regulations.

20 D.A. Saurrohmah. (2019). Tinjauan Figh Siyasah terhadap kewenangan DKPP dalam penyelesaian pelanggaran kode etik Pemilihan Umum: studi putusan DKPP nomor 23-25/DKPP-PKE-I/2012 (Doctoral dissertation, UIN Sunan Ampel Surabaya). p. 34.

${ }^{21}$ Nur Hidayat Sardini, Mekanisme Penyelesaian Pelanggaran Kode Etik Penyelenggara Pemilu, (Jakarta: LP2AB (Lembaga Pendidikan Anak Bangsa, 2015). p. 180. 
With the provision of firm and fair sanction to Ad Hoc Board that violate the Ethics and Conduct Code, it will give deterrent effect on other $A d$ Hoc Board members.

2. The registration mechanism for Ad Hoc Board is in accordance with the applicable rules and procedures

In the admission stage for the registration of an Ad Hoc Board, the rewuirements must be in accordance with applicable procedures and regulations, so that the applicant meets the applicable regulation criteria. For example, and $A d H o c$ Board member must be neutral and not become a member of a political party, domiciled in the work area. Respectively, and so forth.

3. Carry out socialization and guidance on Ethics and Conduct Code to $A d$ Hoc Board on an ongoing basis

The Chairperson and members of Bolaang Mongondow KPU, especially the Head of the Legal and Supervision Division, always carry out socialization and guidance related to Ethics and Conduct Code which is carried out gradually and continuously to existing Ad Hoc Board.

4. Area mapping related to potential Ethics and Conduct Code violation The Bolaang Mongondow KPU has a wide working area and each subdistrict/village has different regional characteristic, culture or habits so that it requires area mapping related to potential Ethics and Conduct Code violation. For example, for sub-district/village that are far from regency cities and there are no telephone network should be visited and supervised continuously so there will be reduced Ethics and Conduct Code violation.

\section{CONCLUSION}

This research conclusion can be expressed that; the repressive action against the Ad Hoc Board Ethics and Conduct Code violation at Bolaang Mongondow KPU in the election of North Sulawesi Governor and Deputy Governor 2020, had been carried out in accordance with applicable laws and regulations. There were 5 (five) cases of Ethics and Conduct Code violations carried out by Ad Hoc Board of Bolaang Mongondow KPU. There are several efforts to prevent Ethics and Conduct Code violations in Bolaang Mongondow KPU, which are: giving firm and fair sanctions, making sure that the registration mechanism for Ad Hoc Board in accordance with applicable procedures and regulations, carrying out socialization and guidance on the Ethics and Conduct Code to Ad Hoc Board on an ongoing basis, mapping area related to Ethics and Conduct Code violations. 


\section{DECLARATION OF CONFLICTING INTERESTS}

None

\section{FUNDING INFORMATION \\ None}

\section{ACKNOWLEDGEMENT}

The author would like to thank Udayana University as a place to gain the best legal knowledge for writer's knowledge development. The author would also like to thank Bolaang Mongondow KPU, which had been willing to be writer's research site. Finally, writer hopes this research will be useful for Indonesia science advancement.

\section{REFERENCES}

Akbar, A. (2019). Pemberhentian Anggota Komisi Pemilihan Umum Berdasarkan Pelanggaran Kode Etik. (Universitas Sriwijaya).

Asshiddiqie, J. (2006). Partai Politik Dan Pemilihan Umum Sebagai Instrumen Demokrasi. Jurnal Konstitusi, 4.2), 6-27.

Basriadi, B. (2009). Tugas dan Kewenangan KPU dalam memverifikasi partai politik peserta pemilu di Indonesia menurut UU Number 2 tahun 2008 dan UU no. 10 tahun 2008 dalam perspektif fiqh siyasah (Doctoral dissertation, IAIN Sunan Ampel Surabaya).

DKPP Regulation Number 2 of 2017 concerning Ethics and Conduct Code of KPU (Republic Indonesia's State Gazette of 2017 Number 1338);

DKPP Regulation Number 3 of 2017 concerning Guidelines for Conducting the Ehic and Conduct Code for KPU (Republic Inonesia's State Gazette of 2017 Number 1404) as amended by DKPP Regulation Number 2 of 2019 (Republic Indonesia's State Gazette of 2019 Number 291);

Fadlian, A. (2016). Pengaruh Putusan Dewan Kehormatan Penyelenggara Pemilihan Umum terhadap Hasil Pemilihan Gubernur Lampung 2014. FIAT JUSTISIA: Jurnal Ilmu Hukum, 10(4), 777-794.

Fahmi, Irham. (2013). Etika Bisnis. Bandung: Alfabeta.

Jimly, A.-S. (2006). Pengantar Ilmu Hukum Tata Negara. Jakarta: Sekretariat Jenderal dan Kepaniteraan Mahkamah Konstitusi.

Kartoningrat, Besse, R. (2016). Fungsi Etika Profesi Bagi Kurator Dalam Menjalankan Tugas, Jurnal Perspektif, 2.21, 113-124.

Ketua Divisi Hukum dan Pengawasan KPU Kabupaten Bolaang Mongondow (2021), Wawancara Personal, 23 Februari 2021. 
Khan, Syamsul, \& Djuyandi, Y. (2020). Implementasi Regulasi Pemilihan Umum Tahun 2019 Yang Tidak Matang (Studi Kasus KPU Kab. Banggai), Wacana Publik, 14.2, 21-43.

KPU Decree Number 337/HK.06.2-Kpt/01/KPU/VII/2020 concerning Technical Guidelines for Repressive Action against Violation of the Ethics and Conduct Code, Oaths/Promises and/or Integrity Pact of Members of the PPK, PPS and KPPS;

KPU Regulation Number 15 of 2019 concerning te Stages, Programs and Schedules for Organizing the Election for Governor and Deputy Governors, Regents and Deputy Regents and/or Mayors and Deputy Mayors in 2020 (Republic Indonesia's State Gazette of 2019 Number 905) as amended several times, most recently by KPU Regulation Number 5 of 200 concerning the Third Amendment to the KPU Regulation Number 15 of 2019 (Republic Indonesia's State Gazette of 2020 Number 615);

KPU Regulation Number 3 of 2015 concerning the Work Procedures of the KPU, the Provincial Level KPU/Independent Election Commission of Aceh and KPU/Independent Election Commission of Regency/City, Establishment of Work Procedures for PPK, PPS and KPPS in Organizing Election for Governors, Regents and Deputy Regents and/or Mayors and Deputy Mayors as amended most recently by the KPU Regulation Number 13 of 2017;

KPU Regulation Number 8 of 2019 concerning concerning Work Procedures for KPU, Provincial Level KPU, and Regency/City Level KPU (Republic Indonesia's State Gazette of 2019 Number 320) as amended by KPU Regulation Number 3 of 2020 concerning Amendments to the KPU Regulation Number 8 of 2019 concerning Work Procedures for KPU, Provincial Level KPU, and Regency/City Level KPU (Republic Indonesia's State Gazette of 2020 Number 201);

Law Number 1 of 2015 concerning Stipulation of Government Regulations in Lieu of Law Number 1 of 2014 concerning the Governors, Regents, and Major Election into law (Republic of Indonesia's State Gazette of 2015 Number 23, Republic Indonesia's Supplement to State Gazette Number 5656) as amended several times, most recently by Law Number 6 of 2020 concerning Stipulation Government Regulation in Lieu of Law Number 2 of 2020 concerning the Third Amendment to Law Number 1 of 2015 concerning Stipulation of Government Regulation in Lieu of Law Number 1 of 2014 concerning the Governors, Regents, and Major into law (Republic of Indonesia's State Gazette of 2020 Number 193, Republic Indonesia's Supplement to State Gazette Number 6547). 
Maki, K. I., Rumokoy, D. A., \& Gerungan, C. A. (2020). Kewenangan Dewan Kehormatan Penyelenggara Pemilu Republik Indonesia Dalam Memutus Pelanggaran Kode Etik, Lex Administratum, 8.4, 5-14.

North Sulawesi KPU Decree Number 69/PP.01.2-Kpt/71/Prov/VI/2020 concerning the Second Amandment to the North Sulawesi KPU Decree Number 138/PP.01.2-Kpt/71/Prov/X/2019 concerning Technical Guidelines for Stages, Programs and Schedules for Organizing the 2020 North Sulawesi Governor and Deputy Governor Election.

Noviati, C. E. (2013). Demokrasi Dan Sistem Pemerintahan. Jurnal Konstitusi, $10.2,333-354$.

Pendidikan, Departemen dan Kebudayaan Republik Indonesia. (1988). Kamus Besar Bahasa Indonesia. Jakarta: Balai Pustaka.

Sardini, N. H. (2015). Mekanisme Penyelesaian Pelanggaran Kode Etik Penyelenggara Pemilu, Jakarta: LP2AB (Lembaga Pendidikan Anak Bangsa, , 174-182.

Saurrohmah, D. A. (2019). Tinjauan Fiqh Siyasah terhadap kewenangan DKPP dalam penyelesaian pelanggaran kode etik Pemilihan Umum: studi putusan DKPP nomor 23-25/DKPP-PKE-I/2012 (Doctoral dissertation, UIN Sunan Ampel Surabaya).

State Constitution of the Republic of Indonesia 1945.

Sukriono, D. (2009).Menggagas Sistem Pemilihan Umum Di Indonesia. Jurnal Konstitusi Kanjuruhan, 2.1, 1-36.

Waluyo, B. (2002). Penelitian Hukum Dalam Praktek. Jakarta: Rineka Cipta.

Warjiyati, S. (2020). Penataan Struktur dan Kewenangan Komisi Pemilihan Umum, Badan Pengawas Pemilu dan Dewan Kehormatan Penyelenggara Pemilu dalam Upaya Mewujudkan Pemilihan Umum yang Demokratis di Indonesia. ARISTO, 8(1), 27-41.

Zetra, A., Chatra., dan Sari, Y. (2017).Pelanggaran Kode Etik Berat Oleh Anggota KPU Kabupaten/ Kota Di Provinsi Sumatera Barat Pada Pemilu Tahun 2014 Dan Pilkada Tahun 2015. Jurnal Ilmu Sosial, 16.1, 2030.

Ziha, P. F. (2018). Implementasi Peraturan Menteri Pekerjaan Umum Dan Perumahan Rakyat Nomor 7 Tahun 2017 Tentang Kode Etik Dan Kode Perilaku Pegawai Dalam Meningkatkan Kinerja Pegawai Di Balai Besar Pelaksanaan Jalan Nasional Ii Medan (Doctoral dissertation). 


\section{ABOUT AUTHOR(S)}

Ni Made Desika Ermawati Putri, was born in Banyuwangi on December 22, 1994. She studied elementary school at SD Negeri 5 Watukebo (2000-2006), junior high school at SMP Negeri 2 Rogojampi (2006-2009), SMK at SMK PGRI Rogojampi (2009-2012), S1 at the Faculty of Law Udayana University (20122016) when S1 was active in organizational activities including ALSA (Asian Law Student's Association) LC UNUD, UMCC (Udayana Moot Court Community), currently pursuing a Master's Degree in Master of Law at Udayana University. Currently as an ASN at the KPU Bolaang Mongondow Regency, North Sulawesi Province and is placed as an executor in the legal subsection (2019-present). 